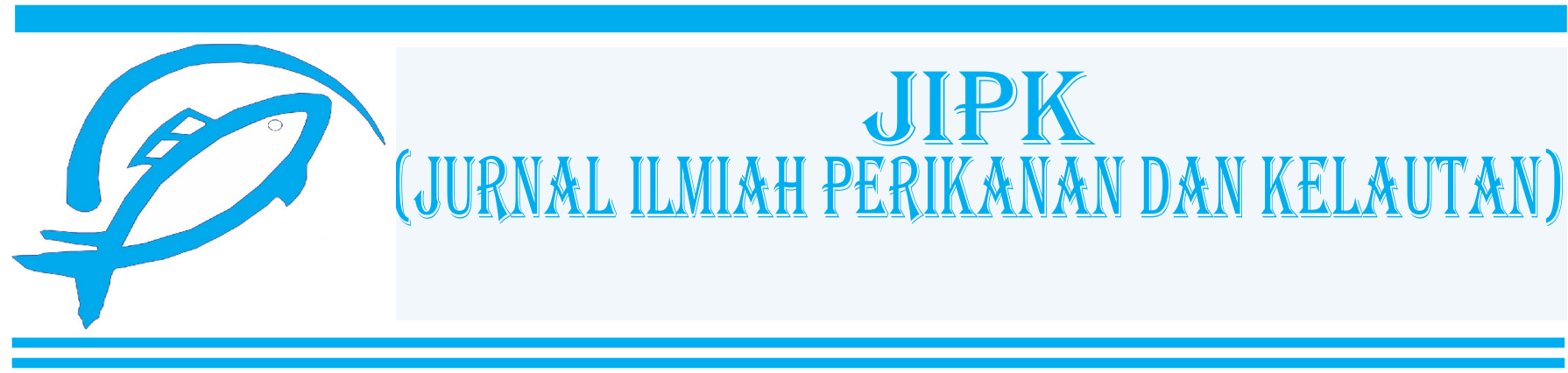

Research Article

\title{
The Effect of Plastic Waste Attachment on Branching Coral to Zooxanthellae Abundance in the Kelapa Dua Island Waters, Seribu Islands, Indonesia
}

\author{
Fadel Muhammad ${ }^{1,4}$ D, Meutia Samira Ismet ${ }^{1}$, Muhammad Irlan Assidiq Kusuma Ramadhan², and \\ Neviaty P. Zamani ${ }^{1,3 *}$ \\ ${ }^{1}$ Department of Marine Science and Technology, Faculty of Fisheries and Marine Science, IPB University, Bogor, 16680. \\ Indonesia. \\ ${ }^{2}$ Vrije Universiteit Brussel, Pleinlaan 2, Brussel, 1050. Belgium. \\ ${ }^{3}$ Center for Transdisciplinary and Sustainability Science, IPB University, Bogor, 16144. Indonesia. \\ ${ }^{4}$ Coastal and Marine Resources Management Center (BPSPL) Padang, Marine and Fisheries Affairs of Indonesia. Indonesia
}

\section{OPEN ACCESS}

\section{$\underline{\text { ARTICLE INFO }}$}

Received: January 02, 2021

Accepted: February 25, 2021

Published: March 31, 2021

*) Corresponding author:

E-mail: neviaty@apps.ipb.ac.id

Keywords:

Clear Plastic

Plastic Sack

Plastic Packaging

Black Plastic

Light Intensity

This is an open access article under the CC BY-NC-ND license (http://creativecommons.org/licenses/by-nc-nd/4.0/)

\begin{abstract}
Coral growth in Indonesia was being disrupted due to the continued threat of environmental change, such as littering to the beach. This study aimed to analyze the effect of the attachment of different colored plastic waste to the rate of zooxanthellae abundance on branching corals in Kelapa Dua Island waters. Branching coral colony samples consisted of the genus Acropora and Porites with a total of 15 fragments of coral colonies at the depth of 80-90 cm were tested with a treatment of the attachment plastic wastes (control, clear plastic, plastic sack, plastic packaging, and black plastic) for four days. The zooxanthellae abundance was calculated using the APHA (American Public Health Association) formula. The results of zooxanthellae abundance on the closure treatment of branching coral samples with black plastic and control had the lowest and highest values by 4.25 $\times 10^{5}$ cells $/ \mathrm{cm}^{2}$ and $1.38 \times 10^{6}$ cells $/ \mathrm{cm}^{2}$. The results of the linear regression test showed that there was a significant relationship between plastic waste with low light intensity and a decrease of zooxanthellae abundance in coral colonies with the equation $Y$ of $972.78 x+653402$, determination index (R2) of 0.68 , and correlation index (r) of 0.83 . These results indicated that the attachment of plastic waste to branching coral colonies could be a stressor on coral animals in reducing light intensity, which caused a reduction of zooxanthellae abundance as coral endosymbiont.
\end{abstract}

Cite this as: Muhammad, F., Ismet, M. S., Ramadhan, M. I. A. K., \& Zaman, N. P. (2021). The Effect of Plastic Waste Attachment on Branching Coral to Zooxanthellae Abundance in the Kelapa Dua Island Waters, Seribu Islands, Indonesia. Jurnal Ilmiah Perikanan dan Kelautan, 13(1):29-37. http://doi.org/10.20473/jipk.v13i1.18146 


\section{Introduction}

Coral growth in Indonesia was being disrupted due to the continued threat of environmental change (Heery et al., 2018). In coastal areas, for example, the lifestyle of coastal residents and beach tourists can produce various kinds of pollution such as cumulation of garbage around the beach (Loulad et al., 2019), fishing activities in coastal areas which sometimes leave ripped nets that stuck in corals (Al-Jufaili et al., 1999; Bavestrello et al., 1997; Haynes, 1997), and many other human activities that produce marine debris which can disrupt coral health.

In 2010, Indonesia ranked second highest, after China, of countries that produce plastic waste that was not well managed (Jambeck et al., 2015). The report up to 2010 noted that Indonesia was able to produce 3.22 million tons/year of plastic waste that was not well managed of which 0.48-1.29 million tons/year was plastic waste entering marine waters (Jambeck et al., 2015). Jakarta Bay, the central city in Indonesia, is an area with the potential to produce plastic waste that enters marine waters (marine debris) in large quantities (Cordova et al., 2019). This is inseparable from the function of the city of Jakarta as a densely populated capital, besides, Jakarta bay is also an area with a large water volume input sourced from 13 rivers (Sahwan, 2004; Shidqi et al., 2018). It had been proven that Jakarta bay was able to produce up to 23 million tons of plastic waste on average per day from 9 river estuaries (Cordova et al., 2019).

Plastic waste is the largest contributor to the composition of marine debris (Abu-Hilal et al., 2009; Ballesteros et al., 2018; Loulad et al., 2019). The research in the Florida Sea showed that fishing activities accounted for $87 \%$ of fishery waste in the form of nets, plastics, and mines stuck to corals, where $57 \%$ of the waste was stuck on branching corals, $19 \%$ was caught in solid corals, and $13 \%$ were caught on soft corals (Chiappone et al., 2005)however, to assess the impacts of lost fishing gear to benthic organisms and habitat structure. In this study, 63 offshore coral reef and hard-bottom sites were surveyed during 2001 to quantify the impacts of lost fishing gear to coral reef sessile invertebrates. Lost hook-and-line fishing gear accounted for $87 \%$ of all debris $(\mathrm{N}=298$ incidences. The attachment of plastic waste to corals has the potential for degradation in these corals, such as the cause of inhibiting the arrival of light and oxygen on corals (Lamb et al., 2018) and physical damage to corals, so that they can reduce photosynthesis in zooxanthellae (Fachrurrozie et al., 2012; Richards et al., 2011).

The impact caused by different types of plastic waste on coral animals, in particular, is still not well documented. Based on the past research, only Fachrurrozie et al. (2012) who conducted the study about the impact of plastic debris to the coral organism. Furthermore, Fachrurrozie et al. (2012) only used three types of plastic; dark plastic, half dark plastic, and clear plastic. The difference of color in plastic waste allows for different effects on light intensity and the rate of zooxanthellae abundance in corals, so it is necessary to look specifically at the different impacts of each (Fachrurrozie et al., 2012). This study aimed to analyze the effect of sticking different colored plastic waste on the abundance rate of zooxanthellae in branching corals. The results of this study are expected to be a reference for research activists regarding the detailed degradation effects of coral animals from the sticking plastic waste, especially the abundance of zooxanthellae that exists on coral reefs.

\section{Materials and Methods}

\subsection{Location and Time of Research}

The research was conducted in October and November 2019 at Kelapa Dua Island waters, Seribu Islands, DKI Jakarta which included field and laboratory research. The location coordinate of the data collection was at $5^{\circ} 39^{\prime} \mathrm{S}$ and $106^{\circ} 33^{\prime} \mathrm{E}$ (Figure 1). Kelapa Dua Island is a part of the island group in the Seribu Islands which is accessible for tourism activities.

\subsection{Materials}

The tools and materials used in the research were divided into field study equipment and laboratory equipment. Field study equipment included basic diving equipment such as camera (G12, Canon, Japan), coral health chart (coral health chart, University of Queensland, Australia), light meter (LI-250A) with underwater quantum sensors (LI-192SA and LI- 193SA), DO meter (DO-5510, Lutron, USA), pH meter (Pen Type PH-009-A), Refractometer (Master-S28M, Atago, Japan), branched coral sample bottle, cool box, stationery, and plastic waste sample. Meanwhile Laboratory equipment included a binocular microscope (CX22, Olympus, Japan), hemocytometer, cover glass, and dropper pipette. The materials used were lugol as the preservation of post-extracted zooxanthellae samples from coral colonies and seawater as storage media for branched coral samples.

The sampling of branched coral colonies was carried out at a depth of $80-90 \mathrm{~cm}$ from the water surface. Samples of branching coral colonies were observed using a coral health chart to determine healthy coral colonies. The branched coral colonies sampled were coral colonies from the genus Acropora and Porites with a total of 15 coral colony fragments. 


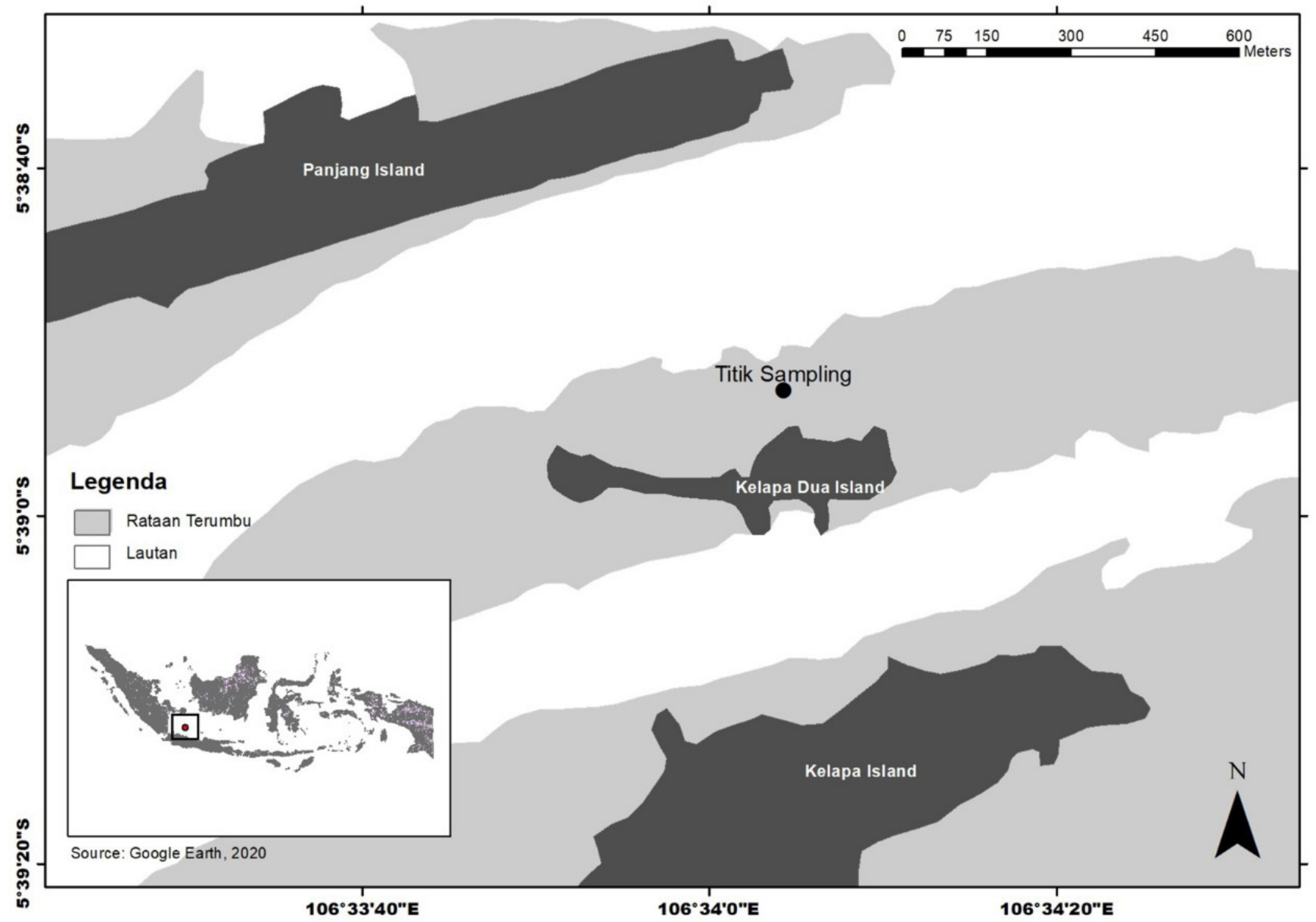

Figure 1. The location of data collection in Kelapa Dua Island waters is the management area of the National Park Management Section (SPTN) Region I of the Seribu Islands Marine National Park. The part shaded with black round marks is the research point of implementation at 5 research 39 'latitude and $106^{\circ} 33^{\prime}$ ' east longitude.

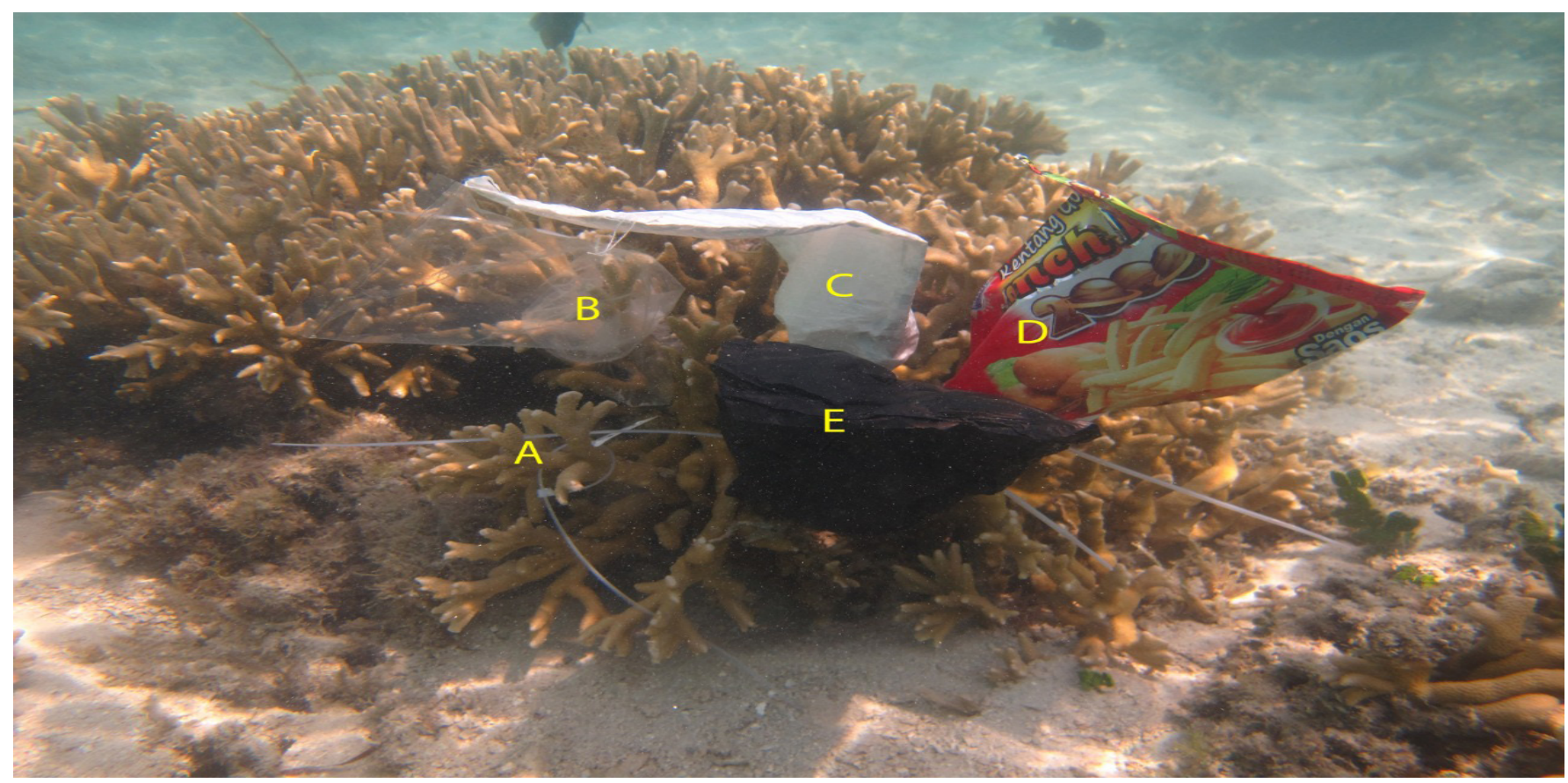

Figure 2. Installation of plastic waste attached to the coral colony for four days. A is the control treatment, B is the sticking treatment with clear plastic, $\mathrm{C}$ is the attachment treatment with plastic sacks, $\mathrm{D}$ is the attachment treatment with plastic packaging, and $\mathrm{E}$ is the attachment treatment with black plastic. 


\subsection{Methods}

\subsubsection{Installation of plastic waste on branched coral samples}

The inorganic waste that would be used as a treatment for branched coral colonies consisted of four types, namely dark black plastic, plastic packaging, plastic sacks, and clear plastic (Figure 2). The plastics were attached to the designated branching coral colonies with three repetitions of each for another branching coral colony not far between points for four days. One branching coral colony had five fragments of branching coral which four fragments were attached by each type of plastic waste and one fragment was control treatment. Then, this study had 15 data for three repetitions.

\subsubsection{Sampling of coral colony fragments}

Fragments of branched coral samples were taken on the last day of field observation then put into a sample container that was already filled with seawater. The volume of $200 \mathrm{ml}$ seawater was taken and put into a $1000 \mathrm{ml}$ beaker glass based on Pudjiarto et al., 2015; Widiarti et al., (2014).

\subsubsection{Zooxanthellae extraction}

The coral fragments were placed in a container such as tray, then sprayed using a spray filled with seawater. This spraying was continued until the coral color turned into white and the mucus produced on the coral skeleton was no longer there. It was assumed that zooxanthellae in corals had been extracted from the inner layer of the coral (endodermis). The sprayed water that was collected in the tray container was put into the sample bottle and given few drops of lugol solution. Each zooxanthellae extraction from coral fragments had different amount of total sprayed water from one another because it depended on the surface area of the coral fragment and the area that had bleaching after it was attached by plastic debris for four days (Asmiati et al., 2017; Pudjiarto et al., 2015; Widiarti et al., 2014). The surface area of branched coral fragments was calculated after zooxanthellae extraction using Image-J software.

\subsubsection{Zooxanthellae observation}

The observations were made using a hemocytometer and covered with a cover glass on a microscope with a magnification of 10 to 40 times (Asmiati et al., 2017; Pudjiarto and Widiarti, 2015). Zooxanthellae density was calculated using the American Public Health Association (1992) or APHA formula as follows;

Cell density of zooxanthellae $\left(\mathrm{cell} / \mathrm{cm}^{2}\right)=(\mathbf{N} \times$ At $\mathbf{x}$ Vt) $\div($ Ac $x$ Vs x As)
Where: $\mathrm{N}=$ number of zooxanthellae counted (cells), At $=$ area of cover glass $\left(\mathrm{mm}^{2}\right), \mathrm{Vt}=$ total sample volume, $A c=$ area of coral colony sample $\left(\mathrm{cm}^{2}\right), \mathrm{Vs}=$ volume of sample used $(\mathrm{ml})$, As $=$ area of hemacytometer $\left(\mathrm{mm}^{2}\right)$.

\subsection{Data analysis}

The relationship of zooxanthellae abundance with different colored plastic waste was analyzed using linear regression analysis to see the correlation between variables based on the correlation coefficient (r) and the coefficient of determination $\left(\mathrm{R}^{2}\right)$. The value of the correlation coefficient which ranged from -1 to +1 where the coefficient value was getting closer to -1 or +1 , showed the greater influence of the independent variable on the dependent variable. Furthermore, the value of the coefficient of determination $\left(\mathrm{R}^{2}\right)$ was obtained based on the results of the square of the correlation coefficient (r) then converted to a percentage value. The ANOVA (Analysis of Variance) Single Factor test was conducted to test the significance of the data. All analysis were performed using Microsoft Excel 2016.

\section{Result and Discussion}

\subsection{The Waters Condition}

The condition of the waters where the research was conducted still showed normal water conditions for coral reef life, both on the first to the last day (Table 1). Sea surface temperature parameters were in the average range of $29.5-30.6^{\circ} \mathrm{C}$, then the salinity was in the range of $31.4-32.4 \%$ oo $\mathrm{pH}$ was in the range of 8 , and dissolved oxygen (DO) was in the range of $6.3-8 \mathrm{mg} / \mathrm{L}$ for four days of observation. The parameter of light intensity in the water was varied because the weather tended to change from sunny to cloudy when the research was conducted. It showed a decrease in the value of the light intensity parameter to be $492.60 \pm 15.68 \mu \mathrm{mol} / \mathrm{m}^{2} \mathrm{sec}$ especially on the last day of observation. This was because the measurement of water quality parameters was only carried out in the morning when the observation had ended.

\subsection{Zooxanthellae Abundance}

The calculation results of the abundance of zooxanthellae in each treatment showed varying values, ranging from $4.25 \times 10^{5}$ to $1.38 \times 10^{6} \mathrm{cells} / \mathrm{cm}^{2}$ (Figure 3). The range of zooxanthellae abundance values was still in the normal range on coral reefs. The range of zooxanthellae abundance in coral animals was between 0.23 x $10^{6}$ to $1.75 \times 10^{6}$ cells $/ \mathrm{cm}^{2}$ (Costa and Amaral, 2000) and $0.27-1.58 \times 10^{6}$ cells $/ \mathrm{cm}^{2}$ (Asmiati et al., 2017). The closure treatment of branched coral samples with black plastic had the lowest zooxanthellae abundance 
value among the other five treatments, namely with an average zooxanthellae abundance of $4.25 \times 10^{5}$ cells/ $\mathrm{cm}^{2}$. The treatment without plastic covering or control showed the opposite result, which had the highest average of zooxanthellae abundance among all treatments, namely $1.38 \times 10^{6}$ cells $/ \mathrm{cm}^{2}$. Each branching coral colony cover treatment with clear plastic, plastic sacks, and plastic packaging had the highest to lowest average zooxanthellae abundance. The abundance of zooxanthellae with clear plastic covering treatment was $1.04 \times 10^{6}$ cells $/ \mathrm{cm}^{2}$, followed by the abundance of zooxanthellae with the plastic sack, and packaging covering treatment with each value of $1.03 \times 10^{6}$ cells $/ \mathrm{cm}^{2}$ and $9.17 \times 10^{5}$ cells $/ \mathrm{cm}^{2}$ respectively.

The difference in the yield of zooxanthellae abundance was also followed by the difference in light intensity produced in each treatment (Table 2). Closing treatment of coral colony samples with plastic packaging was the treatment with the lowest light intensity value, namely $5.29 \mu \mathrm{mol} / \mathrm{m}^{2} \mathrm{sec}$. The treatment of coral colony cover samples with black plastic, plastic sack, clear plastic, and control was followed sequentially from lowest to highest, with each value of $26.18 \mu \mathrm{mol} /$ $\mathrm{m}^{2} \mathrm{sec}, 353.69 \mu \mathrm{mol} / \mathrm{m}^{2} \mathrm{sec}, 508.57 \mu \mathrm{mol} / \mathrm{m}^{2} \mathrm{sec}$, and $666.97 \mu \mathrm{mol} / \mathrm{m}^{2} \mathrm{sec}$.

Table 1. Water parameter values (mean $\pm \mathrm{SD}$ ), including sea surface temperature, salinity, $\mathrm{pH}$, dissolved oxygen (DO), light intensity in the waters, and depth at the study site for four days of observation. The values of these water parameters still show the values that are still included in the criteria for the viability of coral reef organisms.

\begin{tabular}{lllllll}
\hline Day & $\begin{array}{l}\text { SST } \\
\left({ }^{\circ} \mathrm{C}\right)\end{array}$ & $\begin{array}{l}\text { Salinity } \\
(\mathbf{o} / \mathrm{oo})\end{array}$ & $\mathbf{p H}$ & $\begin{array}{l}\text { DO } \\
(\mathrm{mg} / \mathrm{L})\end{array}$ & $\begin{array}{l}\text { Water intensity } \\
(\mu \mathrm{mol} / \mathbf{m} \mathbf{s e c})\end{array}$ & $\begin{array}{l}\text { Depth } \\
(\mathrm{cm})\end{array}$ \\
\hline 0 & $30.37 \pm 0.38$ & $31.67 \pm 0.71$ & $7.99 \pm 0.08$ & $7.97 \pm 1.57$ & $757.51 \pm 365.45$ & $81.56 \pm 13.47$ \\
1 & $30.57 \pm 1.11$ & $32.44 \pm 0.71$ & $7.97 \pm 0.05$ & $6.72 \pm 1.23$ & $733.41 \pm 367.35$ & $82.22 \pm 13.26$ \\
2 & $30.78 \pm 1.06$ & $31.78 \pm 0.67$ & $8.04 \pm 0.07$ & $6.39 \pm 0.78$ & $679.53 \pm 367.68$ & $79.67 \pm 10.16$ \\
3 & $30.51 \pm 0.79$ & $31.89 \pm 1.17$ & $8.06 \pm 0.05$ & $6.26 \pm 0.51$ & $671.82 \pm 300.35$ & $87.33 \pm 3.74$ \\
4 & $29.57 \pm 0.15$ & $32.33 \pm 0.58$ & $8.03 \pm 0.06$ & $6.77 \pm 0.38$ & $492.60 \pm 15.68$ & $83.00 \pm 1.00$ \\
\hline
\end{tabular}

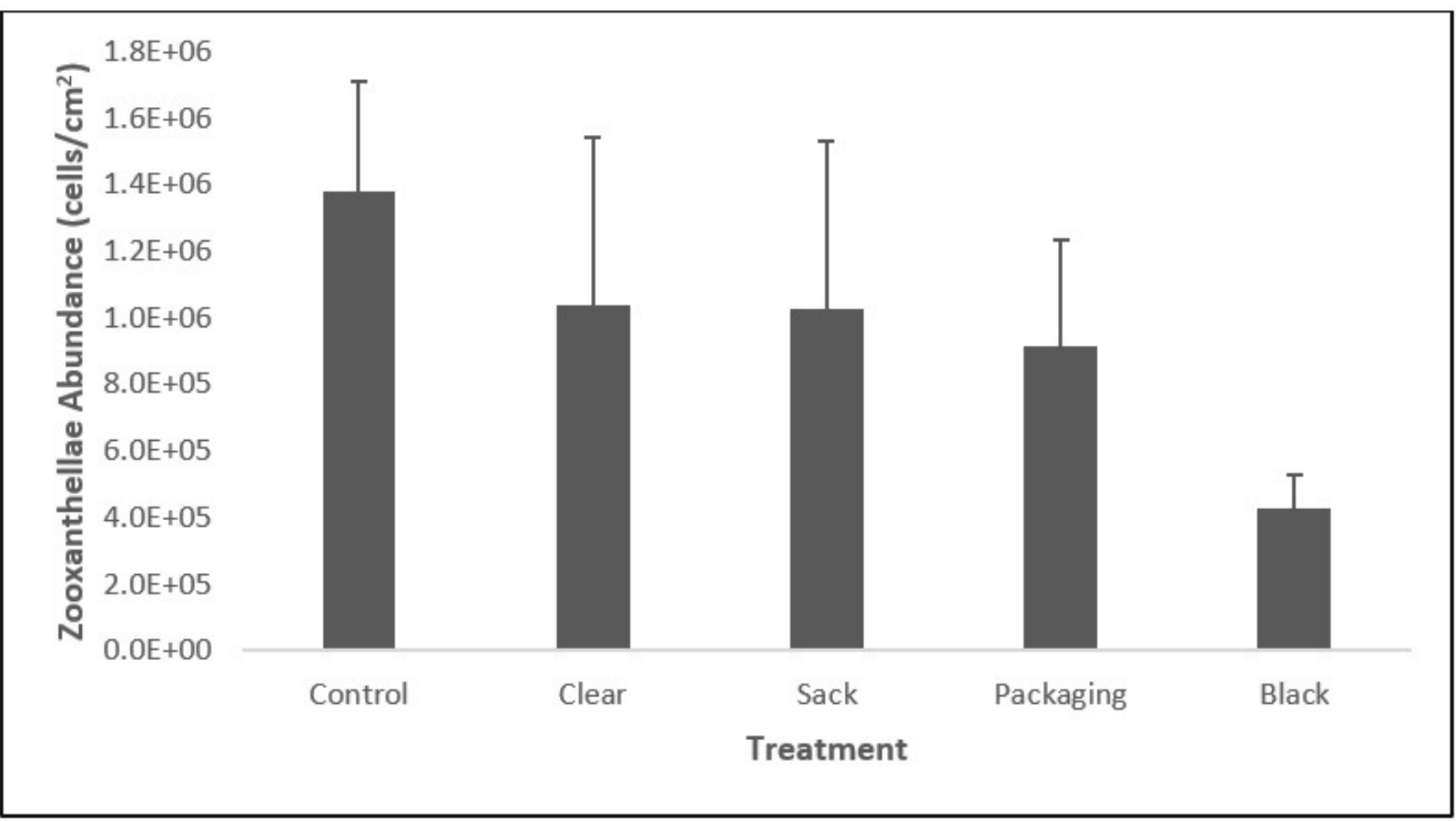

Figure 3. Graph of the average value of zooxanthellae abundance in each treatment of attaching plastic waste to branched coral colonies for four treatment days, where the control treatment, affixing with clear plastic, plastic sacks, plastic packaging, and black plastic had the highest to the lowest zooxanthellae abundance values. Sequentially. The straight line shows the standard deviation value on each chart. 
The differences in trends between the abundance value of zooxanthellae and the value of light intensity in each of the branching coral colony cover treatments were generally related, although there were slight differences. The closure treatment of branched coral colonies with black plastic and plastic packaging was inversely proportional. Other treatments, namely control, clear plastic, and plastic sacks tended to have the same trend when the degradation of the light intensity value was accompanied by a degradation of the abundance value of zooxanthellae in coral colonies. These three treatments were under the principles of the conditions for the existence of coral reef life, where less light intensity resulted in a degradation of coral animals (Kuanui et al., 2020)we investigated the effects of increase and decrease of light intensity and photoperiods on growth, survival, and photosynthetic efficiency in three different corals, Pocillopora damicornis (Linnaeus, 1758, such as reduced photosynthetic ability in zooxanthellae (Jones and Yellowlees, 1997; Rani et al., 2004) which had an impact on the reduced nutrient supply in coral animals, thus resulted in coral mortality (Glynn, 1993; Subhan et al., 2012).

\subsection{Single-factor ANOVA Test Results and Linear Regression on the Five Treatments}

The results of the single factor ANOVA test showed that each treatment of coral colony cover with different colored plastics was not statistically significant. This was based on the calculated F value (F) 2.44 which was smaller than the $\mathrm{F}$ table value (F crit) 3.48 with a constant $\alpha=0.05$, so that $\mathrm{H} 0$ was accepted (Table 3 ). This result was proven in the treatment of clear plastic cover, plastic sacks, plastic packaging, and black plastic in branched coral colonies which still had relatively similar values of zooxanthellae abundance, although there was a decrease in the value trend. These results also proved that zooxanthellae could still be found in low light intensity conditions, even though plastic waste had been covered for four days. Based on this data, it proved that zooxanthellae had high durability and plasticity (Hill et al., 2009; Mwaura et al., 2009) In addition to treatment with the light intensity of $0 \mu \mathrm{molm}^{2} \mathrm{sec}$ for four days, zooxanthellae were still found in coral colonies (Fachrurrozie et al., 2012) and corals of the Platygyra sinensis species were still able to survive even though they were cultured at $0 \mu \mathrm{mol} / \mathrm{m}^{2} \mathrm{sec}$ light intensity for two years (Kuanui et al., 2020)

Long duration of attachment or cover by plastic waste (beyond the treatment period) to branching coral colonies would have a significant effect in degrading the number of zooxanthellae in coral. The results of the linear regression test showed that there was a significant relationship between the attachment of low light intensity plastic waste with a decrease in the abundance of zooxanthellae in coral colonies where the equation $\mathrm{Y}=972.78 \mathrm{x}+653402$ with an index of determination $(R 2)=0.68$ and a correlation index $(r)=0.83$ (Figure 4). This meant that when a branched coral colony was affixed with low-intensity plastic waste for four days, it had degraded the number of zooxanthellae in branched

Table 2. The value of light intensity resulted from the sticking treatment of plastic waste to branching coral colonies (mean $\pm \mathrm{SD}$ ). Attachment to plastic packaging has the lowest light intensity value of $5.29 \mu \mathrm{mol} / \mathrm{m}^{2} \mathrm{sec}$, while the control treatment has the highest light intensity value of $666.97 \mu \mathrm{mol} / \mathrm{m}^{2} \mathrm{sec}$.

\begin{tabular}{lll}
\hline Treatment & $\begin{array}{l}\text { Average of Light Intensity } \\
\left(\boldsymbol{\mu m o l} / \mathbf{m}^{2} \mathbf{s e c}\right)\end{array}$ & $\begin{array}{l}\text { Average of Zooxanthellae } \\
\text { Abundance }\left(\mathbf{c e l l s} / \mathbf{c m}^{2}\right)\end{array}$ \\
\hline Control & $666.97 \pm 103.92$ & $1.38 \times 106 \pm 3.31 \times 105$ \\
Clear Plastic & $508.57 \pm 72.99$ & $1.04 \times 106 \pm 5.02 \times 105$ \\
Plastic Sack & $353.69 \pm 42.07$ & $1.03 \times 106 \pm 5.02 \times 105$ \\
Plastic Packaging & $5.29 \pm 1.09$ & $9.17 \times 105 \pm 3.19 \times 105$ \\
Black Plastic & $26.18 \pm 13.60$ & $4.25 \times 105 \pm 1.05 \times 105$ \\
\hline
\end{tabular}

Table 3. ANOVA (Analysis of Variance) single factor test results on the abundance values of zooxanthellae from each treatment of plastic waste sticking in branched coral colonies. F count $(\mathrm{F})<\mathrm{F}$ table (F crit), with a constant $\alpha=0.05$

\begin{tabular}{|l|c|c|c|}
\hline Source of Variation & $\boldsymbol{F}$ & P-value & F crit \\
\hline Between Groups & 2.44 & 0.11 & 3.48 \\
\hline
\end{tabular}




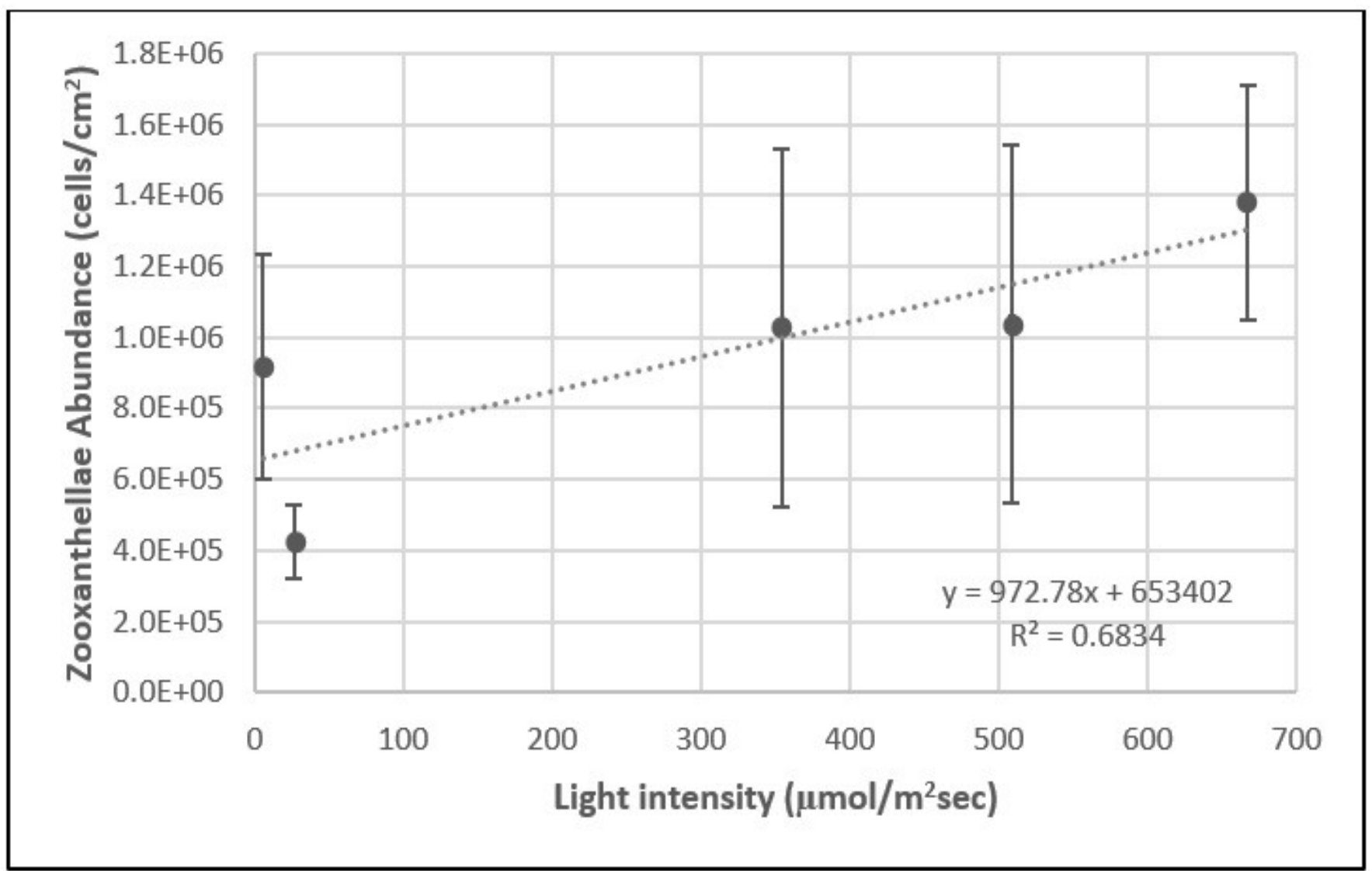

Figure 4. Linear regression test results between light intensity ( $\mu \mathrm{mol} / \mathrm{m}^{2} \mathrm{sec}$ ) and abundance of zooxanthellae cells (cells / $\mathrm{cm} 2) . \mathrm{Y}=972.78 \mathrm{x}+653402$, the index of determination $\left(\mathrm{R}^{2}\right)=0.68$ and the correlation index $(\mathrm{r})=0.83$, indicating that the decrease in light intensity was positively correlated with the decrease in the abundance of zooxanthellae.

coral colonies by $68 \%$. This correlation proved that low light intensity still had the effect of decreasing the number of zooxanthellae in coral colonies (Kuanui et al., 2020)we investigated the effects of increase and decrease of light intensity and photoperiods on growth, survival, and photosynthetic efficiency in three different corals, Pocillopora damicornis (Linnaeus, 1758, if the sticking of plastic waste or other causes (sedimentation) caused a decrease in light intensity to coral colonies occurred continuously. The sedimentation caused degradation of coral reefs, sediment types from silt and clay were the type of sediment that had the most negative impacts on coral animals (Barus et al., 2018). Furthermore, when sedimentation was high, it affected the number of coral genera which was also getting lower (Barus et al., 2018).

In addition to reducing light intensity, the frictional effect of plastic waste on coral colonies had the potential to be another factor that caused damage to coral colonies. Attachment of plastic waste to coral colonies also had the potential to damage the exotic beauty of the sea that coral reefs provide. Thus, it is necessary to be aware of coastal communities and tourists not to use the sea as a garbage dump.

\section{Conclusion}

The treatment of different colored plastic waste sticking to the branching coral colonies gave different effects of zooxanthellae abundance. Attachment of black plastic waste to branched coral colonies was the treatment that had the most impact on reducing the abundance of zooxanthellae. Plastic waste that had a low light intensity value had a positive correlation to a decrease in the value of zooxanthellae abundance in the treatment carried out for four days. The decrease in the abundance of zooxanthellae in low light intensity plastic waste in branching coral colonies proved that intensity had an important role in the existence of coral reef life.

\section{Acknowledgement}

The authors would like to thank fellow graduate students, staff assistants, and lecturers of the Department of Marine Science and Technology, Faculty of Fisheries and Marine Sciences, Bogor Agricultural University for their suggestions and input for the implementation of this research. A big thank you is also addressed to the head of the Seribu Islands Marine National Park, Mrs. Badi'ah, Mr. Yohanes Budoyo, and his staffs, the head 
of SPTN Region I, Mr. Isai Yusidarta and his staffs who have granted access to the conservation area based on the Area Entry Permit. Conservation (SIMAKSI) with number SI.1003 / T.13 / TU / HMS / 10/2019, so that research can be carried out.

\section{Authors' Contributions}

All authors listed in this manuscript contributed to the end. The contributions of each author are as follows, Fadel Muhammad; retrieved and processed the data that obtained in the study. Neviaty P. Zamani and Meutia Samira Ismet; strengthened research ideas, directed research data collection methods, and gave advices for manuscript writing. Muhammad Irlan Assidiq Kusuma Ramadhan; contributed to the English structuring of the manuscripts and data analysis.

\section{Conflict of Interest}

The authors declare that they have no competing interests in this study.

\section{Funding Information}

This research was conducted without any sponsors, but purely derived from personal author (Fadel Muhammad) finance.

\section{References}

Abu-Hilal, A., \& Al-Najjar, T. (2009). Marine litter in coral reef areas along the Jordan Gulf of Aqaba, Red Sea. Journal of Environmental Management, 90(2):1043-1049.

Al-Jufaili, S., Al-Jabri, M., Al-Baluchi, A., Baldwin, R. M., Wilson, S. G., West, F., \& Matthews, A. D. (1999). Human impacts on coral reefs in the Sultanate of Oman. Estuarine, Coastal and Shelf Science, 49(Supp1. 1):65-74._

Asmiati, Palupi, R. D., \& Ira. (2017). Densitas Zooxanthellae berdasarkan bentuk pertumbuhan karang di Perairan Kessilampe dan Bangkutoko Kendari. Sapa Laut, 2(2):37-44.

Ballesteros, L. V., Matthews, J. L., \& Hoeksema, B. W. (2018). Pollution and coral damage caused by derelict fi shing gear on coral reefs around Koh Tao , Gulf of Thailand. Marine Pollution Bulletin, 135(August):1107-1116.

Barus, B. S., Prartono, T., \& Soedharma, D. (2018). Keterkaitan sedimentasi dengan persen tutupan terumbu karang di Perairan Teluk Lampung. Jurnal Ilmu dan Teknologi Kelautan Tropis, 10(1):4958.
Bavestrello, G., Cerrano, C., Zanzi, D., \& Cattaneo-Vietti, R. (1997). Damage by fishing activities to the Gorgonian coral Paramuricea clavata in the Ligurian Sea. Aquatic Conservation: Marine and Freshwater Ecosystems, 7(3):253-262.

Chiappone, M., Dienes, H., Swanson, D. W., \& Miller, S. L. (2005). Impacts of lost fishing gear on coral reef sessile invertebrates in the Florida Keys National Marine Sanctuary. Biological Conservation, 121(2):221-230.

Cordova, M. R., \& Nurhati, I. S. (2019). Major sources and monthly variations in the release of land-derived marine debris from the Greater Jakarta area, Indonesia. Scientific Reports, 9(1):1-8.

Costa, C., \& Amaral, F. (2000, October). Density and size differences of symbiotic dinoflagellates from five reef-building coral species from Brazil. Proceedings of the Ninth International Coral Reef Symposium, Bali, 23-27 Vol. 1.

Fachrurrozie, A., Patria, M. P., \& Widiarti, R. (2012). Pengaruh perbedaan intensitas cahaya terhadap kelimpahan Zooxanthellae pada karang bercabang (Marga: Acropora) di Perairan Pulau Pari, Kepulauan Seribu. Jurnal Akuatika, 3(2):115-124.

Glynn, P. W. (1993). Coral reef bleaching: ecological perspectives. Coral Reefs, 12(1):1-17.

Haynes, D. (1997). Marine Debris on Continental Islands and Sand Cays in the Far Northern Section of the Great Barrier Reef Marine Park, Australia. Marine Pollution Bulletin, 34(4): 276-279.

Heery, E. C., Hoeksema, B. W., Browne, N. K., Reimer, J. D., Ang, P. O., Huang, D., Friess, D. A., Chou, L. M., Loke, L. H. L., Saksena-Taylor, P., Alsagoff, N., Yeemin, T., Sutthacheep, M., Vo, S. T., Bos, A. R., Gumanao, G. S., Syed Hussein, M. A., Waheed, Z., Lane, D. J. W., Todd, P. A. (2018). Urban coral reefs: Degradation and resilience of hard coral assemblages in coastal cities of East and Southeast Asia. Marine Pollution Bulletin, 135(August):654-681.

Hill, R., Ulstrup, K. E., \& Ralph, P. J. (2009). Temperature induced changes in thylakoid membrane thermostability of cultured, freshly isolated, and expelled zooxanthellae from scleractinian corals. Bulletin of Marine Science, 85(3):223-244.

Jambeck, J. R., Geyer, R., Wilcox, C., Siegler, T. R., Perryman, M., Andrady, A., Narayan, R., \& Law, K. L. (2015). Plastic wate inputs from land into the ocean. Science, 347(768):768-771. 
Jones, R. J., \& Yellowlees, D. (1997). Regulation and control of intracellular algae (= zooxanthellae) in hard corals. Phil. Trans. R. Soc. Lond. B, 352(1352):457-468.

Kuanui, P., Chavanich, S., Viyakarn, V., Omori, M., Fujita, T., \& Lin, C. (2020). Effect of light intensity on survival and photosynthetic efficiency of cultured corals of different ages. Estuarine, Coastal and Shelf Science, 235: 106515.

Lamb, J. B., Willis, B. L., Fiorenza, E. A., Couch, C. S., Howard, R., Rader, D. N., True, J. D., Kelly, L. A., Ahmad, A., Jompa, J., \& Harvell, C. D. (2018). Plastic waste associated with disease on coral reefs. Science, 359(6374):460-462.

Loulad, S., Houssa, R., Ouamari, N. EL, \& Rhinane, H. (2019). Quantity and spatial distribution of seafloor marine debris in the Moroccan Mediterranean Sea. Marine Pollution Bulletin, 139(August 2018):163-173.

Mwaura, J., Grimsditch, G., Kilonzo, J., Amiyo, N., \& Obura, D. (2009). Zooxanthellae densities are highest in summer months in Equatorial Corals in Kenya. Western Indian Ocean Journal of Marine Science, 8(2):193-202.

Pudjiarto, R. K., \& Widiarti, R. (2015). Kelimpahan Zooxanthellae pada koloni karang montipora yang terinfeksi black band disease dan white syndrome di Pulau Air, Kepulauan Seribu. Prosiding Simposium Nasional Kelautan Dan Perikanan II Universitas Hasanuddin, Makassar, 80-84.

Pudjiarto, R. K., Widiarti, R., Johan, O., \& Patria, M. P. (2015, December). Kelimpahan Zooxanthellae pada koloni karang yang terinfeksi black band disease dan white syndrome di Pulau Pahawang
Besar dan Pulau Kelagian Kecil, Lampung. Pertemuan Ilmiah Nasional Tahunan XII ISOI Banda Aceh, pp. 213-221.

Rani, C., Jompa, J., \& Amiruddin. (2004). Pertumbuhan tahunan karang keras Porites lutea di Kepulauan Spermonde: hubungannya dengan suhu dan curah hujan. Torani, 14(4):195-203.

Richards, Z. T., \& Beger, M. (2011). A quantification of the standing stock of macro-debris in Majuro lagoon and its effect on hard coral communities. Marine Pollution Bulletin, 62(8):1693-1701.

Sahwan, F. L. (2004). Strategi pengelolaan sampah di kawasan Kepulauan Seribu. Jurnal Teknologi Lingkungan. P3TL-BPPT, 5(1):12-16.

Shidqi, R. A., Pamuji, B., Sulistiantoro, T., Risza, M., Derystia, E., Hartini, R., Valentina, B., \& Zul, R. (2018). Coral health monitoring at Melinjo Island and Saktu Island: Influence from Jakarta Bay. Regional Studies in Marine Science, 18:237-242.

Subhan, B., Soedharma, D., Arafat, D., Madduppa, H., Rahmawati, F., Ervinia, A., Bramandito, A., Khaerudi, D., \& Ghozali, A. T. (2012). Pengaruh cahaya terhadap tingkat kelangsungan hidup dan pertumbuhan karang lunak Lobophytum strictum (Octocoralia: Alcyonacea) Hasil Transplantasi pada Sistem Resirkulasi. Jurnal Teknologi Perikanan Dan Kelautan, 3(2):35-42.

Widiarti, R., Johan, O., \& Pudjiarto, R. K. (2014, November). Kelimpahan Zooxanthellae pada koloni karang montipora yang terinfeksi black band disease dan white syndrome di Pulau Pramuka, Kepulauan Seribu. Pertemuan Ilmiah Nasional Tahunan XI ISOI Balikpapan, pp. 156-162. 